\title{
Energy poverty: Estimating the impact of solid cooking fuels on GDP per capita in developing countries - Case of sub-Saharan Africa
}

\author{
Ifeoluwa Garba ${ }^{\mathrm{a}, \mathrm{b},}$, , Richard Bellingham ${ }^{\mathrm{b}}$ \\ ${ }^{a}$ Centre for Doctoral Training, Department of Electrical and Electronic Engineering, University of Strathclyde, Glasgow, United Kingdom \\ ${ }^{\mathrm{b}}$ Institute for Future Cities, University of Strathclyde, 99 George Street, G1 1RD, Glasgow, United Kingdom
}

\section{A R T I C L E I N F O}

\section{Article history:}

Received 9 February 2020

Received in revised form

27 December 2020

Accepted 1 January 2021

Available online 7 January 2021

\section{Keywords:}

Cooking fuels

Developing countries

Economic development

GDP per Capita

Sub-Saharan Africa

\begin{abstract}
A B S T R A C T
Accessibility to modern energy services is imperative in resolving numerous present-day global development issues which affect people's socio-economic and physical well-being, plus, the potentiality of meeting the global goals of lessening carbon emissions. The absence of access, termed energy poverty in developing countries, has several key aspects: inaccessibility to electricity on demand, is one aspect. However, inaccessibility to modern (or clean) cooking fuels is another critical aspect. A cause and effect of households' continuous heavy reliance on traditional (or solid) fuels. Despite over a third of the global population having this issue, this aspect of energy poverty continues to be a severe, yet overlooked development issue: particularly in developing countries. A review of literature shows that there are currently no empirical studies which quantify the sole relationship between the utilization of traditional energy fuels for cooking and/or heating and economic development. Thus, in this paper, we advance existing literature in multiple-folds. Firstly, we provide a review in an absent area of literature. Secondly, using the data from 46 sub-Saharan African countries, we provide empirical evidence of the impacts of the continued utilization of traditional fuels on economic development (employing Gross Domestic Product (GDP) per Capita as variable). Following the establishment of a negative causal relationship running from traditional fuels use (solid) to GDP per capita, we provide an insight into policy implications. Finally, we comment on potential policy strategies.
\end{abstract}

(c) 2021 The Author(s). Published by Elsevier Ltd. This is an open access article under the CC BY license (http://creativecommons.org/licenses/by/4.0/).

\section{o1. Introduction}

In recent years, it has become extensively acknowledged that although accessibility to affordable modern energy by itself is not an elixir for all development problems in developing countries [1,2], it is crucial to economic, social and human development [3,4]. This absence, often labelled as energy poverty, impacts on people's health, productivity, and income [5,6]. More generally, energy poverty acts as a dominant obstacle in attaining development targets including the Sustainable Development Goals (SDGs) [7], and has become one of the key SDGs for 2030 (SDG 7).

In response to this, scientific and policy attention have focussed on matters of accessibility, equity and investment in socialtechnical systems linked to modern energy supply. However,

\footnotetext{
* Corresponding author. Centre for Doctoral Training, Department of Electrical and Electronic Engineering, University of Strathclyde, Glasgow, United Kingdom.

E-mail addresses: ife.garba@strath.ac.uk (I. Garba),richard.bellingham@strath. ac.uk (R. Bellingham).
}

most of this focus has been predominantly placed on electricity supply [8]. This is perhaps due to studies which have demonstrated the importance of electricity on aspects of sustainable development such as, improved productivity driving economic development [9], and improved lighting for day-to-day activities, driving social development [10,11].

Best and Burke [12]; Hirsh and Koomey [13]; and Chakamera and Alagidede [14] amongst several exemplary analyses have extensively evaluated the link between access and/or increased consumption of electricity and economic development, using GDP per Capita as instrument (see Table 2). The underlying theory of change presented by these studies has demonstrated that the provision of modern, clean electricity stimulates wider economic development which in turn stimulates households changing to cleaner energy supplies [15-17]. Across all of these studies, there is an assumption that the continued use of non-modern energy sources is detrimental to economic development as well as health (see Table 3).

Nevertheless, there remains a significant gap which continues to be overlooked by literature. Using data from the World Bank group, 
Table 1

Summary of empirical studies on energy consumption and economic development.

\begin{tabular}{|c|c|c|c|c|}
\hline Author(s) & Countries & Variables & Methods & Conclusions \\
\hline Ebohon (1996) & Nigeria, Tanzania & $\begin{array}{l}\text { Energy } \\
\text { consumption; GDP }\end{array}$ & Engle-Granger causality & $\mathrm{EC} \leftrightarrow \mathrm{GDP}$ \\
\hline $\begin{array}{l}\text { Soytas and Sari } \\
\text { (2003) }\end{array}$ & South-Africa & $\begin{array}{l}\text { Energy } \\
\text { consumption; GDP }\end{array}$ & Co-integration, causality & $\mathrm{EC} \leftarrow \mathrm{GDP}$ \\
\hline \multirow[t]{2}{*}{$\begin{array}{l}\text { Wolde-Rufael } \\
\text { (2005) }\end{array}$} & 19 African countries & $\begin{array}{l}\text { Energy } \\
\text { consumption; GDP }\end{array}$ & $\begin{array}{l}\text { ARDL bounds test; Toda and } \\
\text { Yamamoto causality }\end{array}$ & EC $\rightarrow$ GDP (Cameroon, Morroco and Nigeria) \\
\hline & & & & $\begin{array}{l}\text { EC } \leftarrow \text { GDP (Algeria, Congo DR, Egypt, Ghana and Ivory Coast) } \\
\text { EC } \leftrightarrow \text { GDP (Gabon and Zambia) } \\
\text { EC } \leftrightarrow \text { GDP (Benin, Congo RP, Kenya, Senegal, South Africa, Sudan, } \\
\text { Togo, Tunisia and Zimbabwe) }\end{array}$ \\
\hline Akinlo (2008) & $\begin{array}{l}11 \text { sub-Saharan } \\
\text { countries }\end{array}$ & $\begin{array}{l}\text { Energy } \\
\text { consumption; GDP }\end{array}$ & ARDL bounds test & EC $\Leftrightarrow$ GDP (Cameroon, Ivory Coast, Kenya, Nigeria and Togo) \\
\hline $\begin{array}{l}\text { Wolde-Rufael } \\
\text { (2009) }\end{array}$ & $\begin{array}{l}\text { Algeria, Benin and South } \\
\text { Africa }\end{array}$ & $\begin{array}{l}\text { Energy } \\
\text { consumption; GDP }\end{array}$ & Toda and Yamamoto causality & $\mathrm{EC} \leftrightarrow \mathrm{GDP}$ \\
\hline $\begin{array}{r}\text { Odhiambo } \\
(2009 a)\end{array}$ & Tanzania & $\begin{array}{l}\text { Energy } \\
\text { consumption; GDP }\end{array}$ & ARDL bounds test & $\mathrm{EC} \rightarrow \mathrm{GDP}$ \\
\hline \multirow[t]{2}{*}{$\begin{array}{l}\text { Odhiambo } \\
\text { (2010) }\end{array}$} & $\begin{array}{l}\text { Congo RD, Kenya and } \\
\text { South Africa }\end{array}$ & $\begin{array}{l}\text { Energy } \\
\text { consumption; GDP }\end{array}$ & ARDL bounds test & EC $\rightarrow$ GDP (Kenya, South Africa) \\
\hline & & & & $\mathrm{EC} \leftarrow \mathrm{GDP}($ Congo RD) \\
\hline \multirow[t]{3}{*}{ Esso (2010) } & 7 African countries & $\begin{array}{l}\text { Energy } \\
\text { consumption; GDP }\end{array}$ & Threshold cointegration & EC $\leftarrow$ GDP (Congo and Ghana) \\
\hline & & & & EC $\leftrightarrow$ GDP (Ivory Coast) \\
\hline & & & & EC $\Leftrightarrow$ GDP (Cameroon, Kenya, Nigeria and South Africa) \\
\hline
\end{tabular}

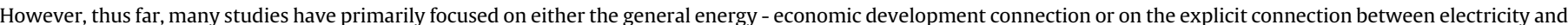
economic development [36].

Table 2

Summary of empirical studies on electricity consumption and economic development.

\begin{tabular}{|c|c|c|c|c|}
\hline Author(s) & Countries & Variables & Methods & Conclusions \\
\hline Abosedra & Lebanon & $\begin{array}{l}\text { Electricity } \\
\text { consumption; GDP }\end{array}$ & Granger causality & $\mathrm{ELC} \rightarrow \mathrm{GDP}$ \\
\hline Akinlo (2007) & Nigeria & $\begin{array}{l}\text { Electricity } \\
\text { consumption; GDP }\end{array}$ & $\begin{array}{l}\text { Johansen-Juselius; Cointegration; VEC; co- } \\
\text { feature analysis }\end{array}$ & $\mathrm{ELC} \rightarrow \mathrm{GDP}$ \\
\hline Jumbe (2004) & Malawi & $\begin{array}{l}\text { Electricity } \\
\text { consumption; GDP }\end{array}$ & Granger causality; ECM & EC $\leftarrow$ GDP $($ Granger $) ;$ ELC $\leftrightarrow$ GDP $($ ECM $)$ \\
\hline $\begin{array}{l}\text { Ouedrago } \\
\quad(2010)\end{array}$ & Burkina Faso & $\begin{array}{l}\text { Electricity } \\
\text { consumption; GDP }\end{array}$ & ARDL bounds test & $\mathrm{ELC} \rightarrow \mathrm{GDP}$ \\
\hline $\begin{array}{c}\text { Odhiambo } \\
\text { (2009) }\end{array}$ & Tanzania & $\begin{array}{l}\text { Electricity } \\
\text { consumption; GDP }\end{array}$ & ARDL bounds test; cointegration; VEC & $\mathrm{ELC} \rightarrow \mathrm{GDP}$ \\
\hline $\begin{array}{l}\text { Odhiambo } \\
\text { (2009) }\end{array}$ & South Africa & $\begin{array}{l}\text { Electricity } \\
\text { consumption; GDP }\end{array}$ & Johansen-Juselius; cointegration; VEC & $\mathrm{ELC} \leftrightarrow \mathrm{GDP}$ \\
\hline \multirow[t]{4}{*}{$\begin{array}{l}\text { Wolde-Rufael } \\
\text { (2006) }\end{array}$} & $\begin{array}{l}18 \text { African } \\
\text { countries }\end{array}$ & $\begin{array}{l}\text { Electricity } \\
\text { consumption; GDP }\end{array}$ & Todo-Yamamoto causality & ELC $\rightarrow$ GDP (Benin, Congo DR, Tunisia) \\
\hline & & & & $\begin{array}{l}\text { ELC } \leftarrow \text { GDP (Cameroon, Gabon, Ghana, Nigeria, Senegal, Zambia } \\
\text { and Zimbabwe) }\end{array}$ \\
\hline & & & & ELC $\leftrightarrow$ GDP (Egypt, Morocco) \\
\hline & & & & ELC $\Leftrightarrow$ GDP (Algeria, Congo RP, Kenya, South Africa and Sudan) \\
\hline
\end{tabular}

Table 3

Summary of empirical studies on biomass consumption and economic development.

\begin{tabular}{|c|c|c|c|c|}
\hline Author(s) & Countries & Variables & Methods & Conclusions \\
\hline $\begin{array}{l}\text { Bildirici } \\
\qquad(2016)\end{array}$ & 8 African countries & Wood consumption (W); GDP & $\begin{array}{l}\text { ARDL bounds test; Granger } \\
\text { causality }\end{array}$ & $\begin{array}{l}\text { W } \leftrightarrow \text { GDP (Benin, Mauritania, Nigeria and South Africa) } \\
\text { W } \rightarrow \text { GDP (Angola, Guinea-Bissau and Niger) } \\
\mathrm{W} \leftarrow \text { GDP (Seycelles) }\end{array}$ \\
\hline $\begin{array}{l}\text { Adewuyi } \\
(2017)\end{array}$ & $\begin{array}{l}\text { Some west African } \\
\text { countries }\end{array}$ & Biomass (B); CO2 emission; GDP & Granger causality & $\begin{array}{l}\mathrm{B} \rightarrow \mathrm{GDP} \text { (Benin, Burkina-Faso, Gambia, Ghana, Mali, Nigeria } \\
\text { and Senegal) } \\
\mathrm{B} \rightarrow \mathrm{GDP} \rightarrow \mathrm{CO} 2 \text { (Burkina-Faso, Gambia, Mali, Nigeria and } \\
\text { Togo) }\end{array}$ \\
\hline $\begin{array}{l}\text { Ozturk } \\
\qquad(2015)\end{array}$ & $\begin{array}{l}\text { Some sub-Saharan } \\
\text { countries }\end{array}$ & $\begin{array}{l}\text { Biomass (B); Openness (O); Population } \\
\text { (P); GDP }\end{array}$ & OLS and DOLS; cointegration & $\mathrm{B}+\mathrm{O}+\mathrm{P} \rightarrow \mathrm{GDP}$ \\
\hline
\end{tabular}

across the world, while about 1.2 billion people still lack access to electricity, over 2.7 billion people still lack access to clean cooking fuels. For these population, the continued use of solid fuels for dayto-day activities such as cooking and/or heating is a necessity [18].
Studies such as Zulu and Richardson [19]; Hammond [20]; and Schlag [21] have established that previous assumptions that electricity could be used to address these needs, have been proven inaccurate $[8,22]$. Yet despite this, studies looking into the issue of 
clean energy for cooking and/or heating, as well as empirical studies investigating the link between the use of solid fuels for cooking and sustainable economic development are few and far between [23]. In fact, upon thorough review of literature, we find less than a handful of studies investigating the link between inaccessibility to clean energy for cooking and/or heating, and economic development.

Thereupon, this paper seeks to address this gap, through an exploration of the dimensions of the relationship between economic development and the use of solid fuels for cooking, in the context of sub-Saharan Africa. The sub-Saharan Africa region is considered in this paper because despite significant global growth in energy from clean and renewable sources, in recent years, subSaharan Africa has one of the highest concentrations of households which continue to use traditional sources of solid fuels for cooking and/or heating [24,25]. Thus, using data from sub-Saharan Africa, we explore this relationship asking two main questions:

- Would enhanced economic development using GDP per Capita as variable, influence the nature of solid fuel trends?

- Or do solid fuel trends influence economic development?

This paper uses the panel co-integration method to explore causality, and to consider the implications for energy policy. The principal contribution of our study is that it gives a perception of the significance of the continued use of solid fuels on economic development. From our results, we demonstrate the relationship hypotheses of solid fuel - GDP per Capita. Thus, giving an insight into appropriate policy approaches.

The remaining parts of this work discusses the existing empirical literature in section 2. Section 2.1 specifically depicts solid fuel use and economic activities in sub-Saharan Africa. The data and methodologies used in these analyses are discussed in section 3. Section 3.2 outlines the four stages associated with the panel cointegration approach, and summarise the basis for the subsequent analyses. Section 4 presents the results of these analyses, before turning to discuss wider significance, implications and conclusions in section 5 .

\section{Literature review}

The pioneering study by Kraft and Kraft in 1978 [26] which demonstrated the presence of a unidirectional causal link between GNP and energy consumption, using data from the United States, provoked an extensive interest in the area of energy consumptioneconomic development nexus. Alone, the study by Ozturk [27] highlights that over sixty studies have investigated this link empirically. Indeed, the studies demonstrating the empirical link between energy and economic development hold important implications. Not only do these studies give important perceptions about the influence of energy on economic development, they also give a premise for the evaluation and design of policies relating to energy and environment. Yet, despite these policy implications, empirical studies on the link between energy consumption and economic development are yet to provide an unequivocal answer. Presently, there exists no unanimity on the nature of the link.

However, existing literature such as the study by Squalli, and the work by Ozturk [27], amongst others, have over the years indicated four potential relationship hypotheses and their policy implications: neutrality, conservation, growth and feedback.

- The neutrality hypothesis refers to cases where no causality link is observed between energy and economic development. Thus, implying that economic development and energy are not correlated. Consequently, for a country with such result, neither energy conservation nor energy expansion policies would influence the economy.

- In the conservation scenario, the causality is observed to run unidirectionally from economic development to energy. Therefore, policies which support the conservation of energy such as policies focusing on demand management, reduction of fossils fuels, amongst others, would not negatively impact on the economy of the country.

- On the other hand, the growth hypothesis denotes scenarios where the causality is observed to run from energy to economic development; meaning the economic development of the country is dependent on energy. This hypothesis implies that directly or indirectly, energy is a crucial determinant in a country's economic development.

- Finally, the feedback hypothesis refers to cases where there exists a bidirectional causal link between energy and economic development. Thus, implying energy and economic development are interconnected.

The work within this study adopts these hypotheses. The analyses will seek to establish the potential hypothesis relationship between the household use of solid fuels and economic development.

\subsection{Energy-economic development nexus in sub-Saharan Africa}

The significance of the inherent implications insinuated by the causal hypotheses have instigated the exploration of the causal relationship between energy and economic development by many scholars [28]. Recently, many of these works explore the causalilty between energy and economic development to encapsulate the fundamental impacts of several current energy issues on development $[29,30]$. This alongside how modern fuels contribute towards livelihood improvement and more extensively, human development [19], have become developing topics.

As regards sub-Saharan Africa, the energy issues experienced in the region's energy sector are becoming well documented and scholars are increasingly investigating the role energy plays in the development of the region. Starting in 1996, using the Granger causality method, Ebohon investigated the causal relationship between energy and economic development in two sub-Saharan countries: Tanzania and Nigeria [31]. More recently, using the Autoregressive Distribution Lag (ARDL) bounds as well as Granger causality method based on vector error correction model (VECM), Akinlo examined the causative link between energy and economic development across eleven sub-Saharan Africa countries [32]. Using the same approach, Odhiambo evaluated the link connecting energy and economic development in Tanzania [33]. The paper by Esso et al., that investigates the causal link between energy and economic development in five African nations [34]; Menegaki's study which looks into the energy-growth nexus for sub-Saharan Africa [35], are amongst recent works attempting to understand this relationship. These studies, along with several other studies which have investigated this causal linkages have observed varying conclusions. (See Table 1).

Recently, this relationship between access and/or increased electricity consumption and economic development has received significant academic and policy attention [37,38]. In 2017, using panel data across 174 countries, Atems and Hotaling [39], investigated the effects of renewable and non-renewable electricity generation on economic development. In their insightful study, Boukhelkhal and Bengana, using the ARDL approach, investigated the impact of electricity consumption on economic development, amongst other indicators, for four north African countries. Also using ARDL as well as the Toda and Yamamoto causality test, Bah 
and Azam examined the link between electricity consumption and economic development in South Africa [40]. In addition to other studies, these studies have examined the causal link between electricity and economic development, with varying and/sometimes contradicting outcomes.

\subsection{Solid fuel and GDP in sub-Saharan Africa}

In 2016, although the continent contributed to only $6 \%$ of the total global energy consumption, Africa contributed to almost $29 \%$ of the global biofuels consumption [41]. In the case of biofuels and biowaste, more than $50 \%$ of the overall energy consumption in the region was derived from these energy forms [42]. In sub-Saharan Africa, biofuels and biowaste contributed to over $70 \%$ of the total energy consumed within the region. Considering only solid biomass, approximately 280 million tonnes of oil equivalent (Mtoe) was consumed in the region - 90\% of which was consumed by households. What's more, over $80 \%$ of the overall energy consumed within households was used for cooking [28].

As previously stated in section 1, despite significant global growth in energy from clean and renewable sources, in recent years, sub-Saharan Africa has one of the highest concentrations of households which continue to use traditional sources of solid fuels for cooking and/or heating [24,25]. In sub-Saharan Africa, the reality remains that over 792 million people depend on traditional fuels such as animal dung, coal, wood, for day-to-day cooking and heating activities [28]. In 2016/17, according to the World Bank, the aggregate access rates for electricity and clean cooking fuels in subSaharan Africa were estimated at approximately $35 \%$ and $20 \%$ respectively. Over the last two decades, access to clean cooking fuels increased with an annual rate of less than $1 \%$ on average.

Yet, although literature acknowledges that many more people across the region lack access to clean cooking fuels than to electricity, much less attention has been given to the resolution of the issue [43].

Studies investigating the link between household use of solid fuels and economic development are limited, and far fewer studies have analysed the impact of household use of solid fuels on economic development. In the recent study by Adewuyi and Awodumi [44], the authors stress that only the study by Ozturk and Bilgili [45] has considered this relationship in the context of sub-Saharan Africa. What's more, these studies are mostly based off of time-series data of individual countries. To our knowledge, there exists no studies which utilise panel unit root and co-integration methods to analyse the solid fuel-economic development relationship. In addition, to the best of our knowledge, there are currently no studies investigating the link between household use of solid fuels and economic development. Thus, this paper makes a contribution to existing literature through investigating the causality between the household use of solid fuels and economic development for forty-six sub-Saharan countries, using the Fully Modified OLS (FMOLS) by Pedroni [46] and Dynamic Ordinary Least Square (DOLS) by Kao [47] methods. We also use panel Vector Error Correction Model (VECM) to check for robustness of the empirical results.

\section{Data and methodology}

Data measuring households utilizing solid fuels as the primary energy sources have been collected primarily through household surveys [48] but have been augmented by estimates for the purposes of the observation of trends and the provision of point estimates for countries and regions in explicit years [41]. Whilst previously there were few national representative surveys, making trend analysis problematic [49], in recent years, increased numbers of national surveys and additional surveys by WHO have expanded available data points [50]. In this analysis, we draw upon this recent data to examine relationships between the household use of solid fuels (hereafter 'solid') and Gross Domestic Product per Capita (hereafter 'GDP') using panel cointegration methods [30,51]. This approach enables relationships between variables to be revealed while allowing for heterogeneity among individual members of the panel.

\subsection{Data}

As previously stated, the analyses performed in this paper are based on data collated by the World Bank Group, for the 46 subSaharan Africa countries [41]. The variables used are based on the annual time series on access to clean cooking fuel and annual time series on Gross Domestic Product (GDP) per capita for these countries, over a period of 15 years. As noted above, data on access to clean cooking fuels has been collected through national surveys and collated into a regional WHO Global Household Energy database [48]. It draws together data gathered at national and subnational levels in most countries using censuses and surveys (see Ref. [48] for measurement methodology). Although measuring energy use, the primary purpose for collecting the data is for their use as proxies for pollution in calculating health impacts (see for example [50,52]). Gross Domestic Product (GDP) per capita is used here as a measure of economic development; data which is frequently used in considering economic growth and trends [53]. Further details of the data can be found on the World Bank website [41].

\subsection{Methodology}

The aim here is to examine the causality link between GDP and solid fuel energy consumption. Previous studies have suggested that panel cointegration techniques are useful to identify causality, especially where relationships are not unidirectional or where time series data is limited [54]. Four stages were undertaken during the investigation. Firstly, the panel unit root tests for the series are performed to examine the stationarity properties of the variables GDP and solid. Next, following the confirmation that the variables are integrated at order one I (1).i.e. after first differencing, cointegration tests are executed. Thirdly, based off of the results from the cointegration analysis stage, if the variables are cointegrated, the cointegration vector is examined utilizing Panel Fully Modified Ordinary Least Square (hereafter FMOLS) and Dynamic Ordinary Least Square (hereafter DOLS). Finally, a panel error correction model is developed to investigate the direction of causality.

\subsubsection{Panel unit roots tests}

Econometric studies such as $[53,55,56]$ have used panel unit root tests to investigate the degree of integration between variables of interest. Accordingly, to fully examine the stationarity characteristics of the variables, we apply five different panel unit tests. The tests applied are: Levin, Lin and Chu (hereafter LLC); Im, Pesaran and Shin (hereafter IPS); Breitung; ADF and PP Fisher (hereafter MW) and Hadri panel unit root tests. The most commonly used panel unit root test is the LLC technique which is based on the Augmented Dickey-Fuller (hereafter ADF) test. LLC assumes that under both the null and alternative hypotheses, all 
groups have the same autoregressive (AR) coefficient [57]. As such, assumes a homogeneous panel.

The IPS technique extends on LLC but allows for heterogeneity by considering the use of averages of the ADF tests and likelihood ratio [58]. Thus, in comparison to LLC, fewer time observations are required for a higher test power ${ }^{1}$ [59].

However, both the LLC and IPS techniques have the disadvantage of assuming independence across the cross-sectional of the panel units [59]. Therefore, to account for the possibility of crosssectional correlation and probable spillage across countries, we apply the Breitung, MW and Hadri techniques. Unlike the LLC and IPS tests which apply bias-corrected estimators, the Breitung test uses unbiased estimators. Thus, it results in a higher test power [60,61].

In contrast to previously mentioned tests which are asymptotic, the MW test is a non-parametric analysis derived from the Fisher test [62]. It combines individual unit root test p-values to obtain results which are non-dependent on the lag lengths of individual ADF regressions. As a result, it has a higher test power in comparison to the LLC and IPS tests [62].

Finally, the Hadri test is a residual-based Lagrange Multiplier (LM) test where OLS residuals are obtained by regressing an output on a constant [63]. The null hypotheses for the various tests are as follows: both the LLC and IPS tests assume a unit root as the null hypothesis (thus non-stationarity); the Breitung null hypothesis assumes that the panel series have non-stationary differences. The MW tests also assume a unit root (non-stationarity) null hypothesis while the Hadri and Heteroscedastic consistent z-stat tests assume a no unit root null hypothesis (stationarity).

\subsubsection{Panel cointegration}

To examine the relationship between use of solid fuel and GDP, the panel cointegration tests created by Pedroni $(1999,2004)$ were used. The test uses heterogeneous panel and heterogeneous group mean panel test statistics to test for panel cointegration between variables $[46,64]$. The relationship is defined as follows:

$G D P_{i, t}=a_{i t}+\beta_{i} t+\delta_{i}$ solid $+\varepsilon_{i t}$

where;

$t=1, \ldots, T ; i=1, \ldots, N$

$t$ represents time across period, $T ; i$ represents panel members across cross-section, $N ; \alpha_{i t}$ represents individual-specific deterministic time trends and $\varepsilon_{i t}$ represents estimated residual which demonstrates the deviation from the long-run relationship [46].

Seven statistics which are categorised into two sets are defined within this test. The panel $v$-statistic; panel $\rho$-statistic; panel PPstatistic and panel ADF-statistic, referred to as 'panel cointegration statistics', are based on the pooling of the residuals along the within dimension of the panel [46]. The group rho-statistic, group PP-statistic and group ADF-statistic, referred to as 'group panel cointegration statistics' are based on the pooling of the residuals along the between dimension of the panel [46].

Since the Pedroni tests assume cross-sectional dependence, we apply further cointegration tests. Kao and Fisher cointegration tests are used for robustness check. The Kao test (also residual based) is derived from the Engle-Granger procedure [65] while Fisher's test is a non-parametric test based on maximum likelihood [66].

All tests assume a null hypothesis of no cointegration.

\footnotetext{
${ }^{1}$ Power here refers to the probability of rejecting the null when it is false.
}

\subsubsection{Estimating the long run cointegration relationship}

Following the detection of cointegration in the results from stage two, we proceed to evaluate the long-run relationship between solid fuel use and GDP. For this, we apply the panel Dynamic Ordinary Least Square (DOLS) and Fully Modified Ordinary Least Square (FMOLS) tests. Proposed by Mark and Sul, the DOLS test is a parametric asymptotically normally distributed test which adjusts errors through reinforcing the static regressor with the lags, leads and values of regressors in the first differences [67,68]. As such, degrees of freedom are lowered in the process. On the other hand, the FMOLS is a non-parametric test proposed by Pedroni [64,69] which considers correlation between the error term and the first differences of the regressors. Thus, it has fewer assumptions. As a result, although both methods produce consistent error estimates, studies have mixed opinions on which of the tests produces more robust results $[65,70,71]$.

\subsubsection{Panel granger causality tests}

To investigate the direction of causality, we apply the Granger causality test to the observed long-run relationship. Two stages are involved in this process. Firstly, we evaluate the residuals from the DOLS and FMOLS model. Secondly, we fit the evaluated residuals into a vector error correction model. At this point, we test for the source of causality using the statistical results from the coefficients of the lagged dependent variables. We consider the speed of adjustment (coefficient) and significance ( $\mathrm{p}$-value) of the error correction variables to establish the existence (or non-existence) of long-run causality in the results.

The error correction model is designed as follows:

$$
\Delta \text { Solid }=\alpha_{1 i}+\sum^{z} L=1 \gamma_{1 i L} \Delta S O L I D_{i t-L}+\sum^{z} L=1 \gamma_{1 i L} \Delta G D P+\zeta_{1 i t}
$$

$$
\Delta G D P=\alpha_{2 i}+\sum^{z} L=1 \gamma_{2 i L} \Delta G D P_{i t-L}+\sum^{z} L=1 \gamma_{1 i L} \Delta S O L I D+\zeta_{2 i t}
$$

where; $\alpha_{i}, \gamma_{i}$ are adjustment coefficients; $L$ is number of lags.Following this process, we investigate if a short-run causality relationship is present or absent.

\section{Results}

\subsection{Panel unit roots results}

A summary of the results from the various panel unit root tests for the model are displayed in Table 4. The illustrated results demonstrate the stationarity (or lack of) properties of the variables as constant, constant-with-trend and first differenced variables.

For the GDP variable (no trend), at level, the null hypothesis of a unit root cannot be rejected at $1 \%$ and $5 \%$ significance levels for all tests; excluding the Hadri and Heteroscedastic consistent z-stat tests which have the null hypotheses of no unit root. For the solid variable, the null hypothesis of a unit root cannot be rejected at $1 \%$ and 5\% significance levels for LLC and IPS tests. At first difference, for both variables, the null hypothesis for all tests can be rejected at $1 \%, 5 \%$ and $10 \%$ significance levels.

As such, the panel unit root condition can be concluded, the variables deemed initially non-stationary but stationary when integrated at order one (I(1)). Thus, fulfilling the conditions required for cointegration analysis. 
Table 4

Results for panel unit root tests for GDP and Solid Fuel Usage.

\begin{tabular}{|c|c|c|c|c|c|c|c|c|}
\hline & \multirow[t]{2}{*}{ Tests } & \multicolumn{5}{|l|}{ Null: Unit root } & \multicolumn{2}{|l|}{ Null: No unit root } \\
\hline & & LLC & IPS & Breitung & ADF - Fisher & PP - Fisher & Hadri & z-stat \\
\hline \multicolumn{9}{|l|}{ Variable } \\
\hline \multirow[t]{4}{*}{ Level } & GDP & $-0.6391(0.2614)$ & $4.7989(1.0000)$ & - & $39.0981(1.0000)$ & $38.3720(1.0000)$ & $16.8465(0.0000)$ & $16.5608(0.0000)$ \\
\hline & GDP (trend) & $-3.7260(0.0001)$ & $-1.2713(0.1018)$ & $-0.6506(0.2577)$ & $103.727(0.0936)$ & $125.063(0.0038)$ & $11.9059(0.0000)$ & $14.0522(0.0000)$ \\
\hline & SOLID & $3.4614(0.9997)$ & $1.4778(0.9303)$ & - & $154.975(0.0000)$ & $220.855(0.0000)$ & $19.4236(0.0000)$ & $20.9639(0.0000)$ \\
\hline & SOLID (trend) & $-22.0322(0.0000)$ & $-32.4615(0.0000)$ & $-1.2549(0.1048)$ & $465.681(0.0000)$ & $425.702(0.0000)$ & $14.3973(0.0000)$ & $31.8515(0.0000)$ \\
\hline \multirow[t]{4}{*}{ First difference } & GDP & $-11.4345(0.0000)$ & $-9.8955(0.0000)$ & - & $257.387(0.0000)$ & $381.983(0.0000)$ & $5.64430(0.0000)$ & $5.15373(0.0000)$ \\
\hline & GDP (trend) & $-12.4084(0.0000)$ & $-6.9440(0.0000)$ & $-6.2492(0.0000)$ & $204.713(0.0000)$ & $383.814(0.0000)$ & $34.3556(0.0000)$ & $30.1044(0.0000)$ \\
\hline & SOLID & $-28.5899(0.0000)$ & $-31.8400(0.0000)$ & - & $462.855(0.0000)$ & $498.473(0.0000)$ & $11.9748(0.0000)$ & $11.0287(0.0000)$ \\
\hline & SOLID (trend) & $-24.2711(0.0000)$ & $-32.0677(0.0000)$ & $-13.521(0.0000)$ & $417.153(0.0000)$ & $405.481(0.0000)$ & $11.5163(0.0000)$ & $12.0685(0.0000)$ \\
\hline
\end{tabular}

Table 5

Results for Pedroni residual cointegration tests.

\begin{tabular}{|c|c|c|c|c|c|c|}
\hline \multirow[t]{2}{*}{ Tests } & \multicolumn{3}{|c|}{ Within panel statistics } & \multicolumn{3}{|c|}{ Between panel statistics } \\
\hline & Type & Statistic & p-value & Type & Statistic & p-value \\
\hline \multirow[t]{4}{*}{ GDP, SOLID } & panel v-statistic & 0.2938 & 0.3845 & group rho-statistic & 1.5652 & 0.9412 \\
\hline & panel rho-statistic & -2.9587 & 0.0015 & group PP-statistic & -1.4196 & 0.0779 \\
\hline & panel PP-statistic & -2.5640 & 0.0052 & group ADF-statistic & -4.8626 & 0.0000 \\
\hline & panel ADF-statistic & -3.8290 & 0.0001 & & & \\
\hline \multirow[t]{4}{*}{ GDP, SOLID (weighted statistic) } & panel v-statistic & -1.4410 & 0.9252 & & & \\
\hline & panel rho-statistic & -0.9927 & 0.1604 & & & \\
\hline & panel PP-statistic & -2.9727 & 0.0015 & & & \\
\hline & panel ADF-statistic & -5.3892 & 0.0000 & & & \\
\hline
\end{tabular}

\subsection{Panel cointegration results}

In Table 5, the results obtained from the Pedroni within and between cointegrated tests are presented. For the unweighted cointegration tests, out of seven tests, we can strongly reject the null hypothesis of no cointegration in four tests (at $1 \%$ significance levels) whilst due to its close p-value, we could consider a 5 th test as marginal.

At $10 \%$ significance level, we can strongly reject the null hypothesis of no cointegration in five tests. For the four weighted statistic tests, the null hypothesis of no cointegration cannot be rejected for the first two tests but can be strongly rejected for the panel PP and ADF statistic tests.

As such, we consider the strong possibility of a long-run relationship between household use of solid fuels and GDP per capita. Accordingly, for robustness check, we consider two further cointegration tests to validate these results.

Table 6 presents the results from Kao's residual panel cointegration test. The obtained result strongly rejects the null hypothesis of zero cointegration at $5 \%$ and $1 \%$ significance levels. Thereupon, confirming the presence of a long-run relationship amongst the variables. Nonetheless, we perform an additional cointegration test to prove (or infirm) the obtained outcomes.

Table 6

Results for Kao's residual cointegration test.

\begin{tabular}{lll}
\hline Model & ADF & p-value \\
\hline GDP, SOLID & -4.268 & 0.000 \\
\hline
\end{tabular}

In Table 7, we present the results from the Fisher-type panel cointegration tests. For the fisher tests, the cointegrating elements are expressed as 'ce'. The tests are then computed under the null hypothesis $H_{0}$ : ce $\leq \mathrm{c}$, alternative hypothesis $H_{1}: c e_{0}>\mathrm{c}$, for the trace test and null hypothesis $H_{0}: c e_{0}=\mathrm{c}$, alternative hypothesis $H_{1}: c e_{0}>\mathrm{c}$ for the max-eigenvalue test. Similar to the Kao's cointegration test, the results obtained from the two analyses: the trace and max-eigen tests strongly reject the null hypotheses of zero cointegration at $1 \%$ significance level: further supporting the existence of cointegration amongst the variables.

Therefore, considering the results obtained from the four (4) tests, the premise of cointegration between the variables is concluded. This implies that the variables move in unison in the long run.

The next stage of the analysis involved evaluating of the longrun elasticities.

\subsection{Long run cointegration results}

Table 8 presents the long-run elasticities obtained from the DOLS and FMOLS models (using 'Solid' as the independent variable). As previously stated in section 3.2.3, the DOLS produces less robust results due to its tendency to add leads and lags to variables. Thus, reducing the degree(s) of freedom. Yet, only DOLS effectively allows for the estimation of trend and direction of causality. As such, although we consider both results, we interpret only the DOLS results. The results obtained for the DOLS model show a negative and significant (at $1 \%$ level) elasticity, between solid fuel use and GDP per capita. The obtained results show a statistically

Table 7

Results for Fisher-type cointegration tests.

\begin{tabular}{|c|c|c|c|c|}
\hline Null hypothesis & Fisher stat* (trace test) & p-value & Fisher stat* (max-eigen test) & p-value \\
\hline ce $=0$ & 1255 & 0.000 & 727.6 & 0.000 \\
\hline ce $\leq 1$ & 180.6 & 0.000 & 180.6 & 0.000 \\
\hline
\end{tabular}


Table 8

Results from DOLS and FMOLS tests.

\begin{tabular}{lll}
\hline & Models & \\
\cline { 2 - 3 } & DOLS & FMOLS \\
\hline Co-efficient & -84.6612 & -45.77895 \\
Std.Error & 16.3579 & 11.03649 \\
t-statistic & -5.1756 & -4.1480 \\
p-value & 0.0000 & 0.0000 \\
\hline
\end{tabular}

significant, negative effect on GDP per Capita and can be interpreted as such. Overall, the estimates of our analyses indicate that there is a strong and significant long-run link between household use of solid fuels and GDP per capita. They indicate that an increase in household use of solid fuels, has a negative impact on GDP per capita.

\subsection{Panel granger causality results}

Following establishing that economic development (GDP per capita) is cointegrated in the long-run with the household use of solid fuels, we investigate the causality between the two variables, using the optimal lag structure of 1: based on the Akaike and Schwarz criteria. The results in Table 9 show the outcomes from the Granger causality test for the optimal lag structure (i.e. a lag of 1 year).

The results highlight the fact that when a long-run causality relationship running from household use of solid fuels to GDP per capita is considered, the null hypothesis of zero causality cannot be accepted at a 5\% significance level for the first lag and at $1 \%$ significance level for further lags. For a long-run causality relationship running from GDP per capita to household use of solid fuels, for the first lag, although marginal at $10 \%$ significance level, the null hypothesis of no causality cannot be rejected at $5 \%$ or $10 \%$ significance levels. For the second lag, the null hypothesis can be rejected at $5 \%$ significance level but cannot be rejected at $1 \%$ significance level. As such, considering that the first lag is deemed the optimal lag, it can be inferred that the long-run relationship runs in only one direction: from household use of solid fuels to GDP per capita.

\subsubsection{Short-run causality}

Finally, we consider the short-run relationship between the two variables. Table 10 presents the results from the short run causality test. The results show that the null hypothesis of no short-run causality can be rejected for the 'Solid' dependent model but

Table 9

Results for Granger causality test ( $\mathrm{L}=$ lags).

\begin{tabular}{llll}
\hline Dependent variable & f-statistic & p-value & Sense of causality \\
\hline GDP & & & \\
SOLID $(\mathrm{L}=1)$ & 4.89562 & 0.0273 & SOLID $\rightarrow$ GDP \\
SOLID $(\mathrm{L}=2)$ & 3.41759 & 0.0135 & \\
SOLID $(\mathrm{L}=3)$ & 3.19592 & 0.0076 & \\
SOLID & & & \\
GDP $(\mathrm{L}=1)$ & 2.69322 & 0.1013 & GDP $\rightarrow$ SOLID \\
GDP $(\mathrm{L}=2)$ & 3.12592 & 0.0447 & \\
GDP $(\mathrm{L}=3)$ & 6.57827 & 0.0070 & \\
\hline
\end{tabular}

Table 10

Short-run causality results.

\begin{tabular}{llll}
\hline Dependent variable & Chi-square & p-value & Sense of causality \\
\hline SOLID & 2.184711 & 0.3354 & GDP $\rightarrow$ SOLID \\
GDP & 9.712422 & 0.0078 & SOLID $\rightarrow$ GDP \\
\hline
\end{tabular}

cannot be rejected for the 'GDP' dependent model. Considering that we can accept the 'Solid $\rightarrow$ GDP' hypothesis at 1\%,5\% and 10\% significance levels, it can be inferred that this result implies that there exists a strong and significant short-run causal relationship running from solid fuel to GDP.

On the whole, the link between household use of solid fuels and GDP per capita is identified by an uni-directional causality running from solid fuels to GDP per capita in both the long-run and shortrun dynamics.

\section{Conclusion and policy implications}

This paper has investigated the empirical evidence of the link between lack of access to clean cooking fuels and economic development: using data from 46 sub-Sahara African countries, for the period of 2000-2015. GDP per capita and percentage of population depending on traditional (solid) fuels were used as variables for the analyses.

For this purpose, we have utilised the panel unit roots tests, panel cointegration and causality methods. The robustness of the results at each stage of the analyses, was tested by utilizing multiple models per stage. In terms of the short-run causality, our estimations indicate that the use of solid fuels has a statistically significant impact on economic development in the short-run for sub-Saharan Africa. An increase in the household use of solid fuels such as coal, animal dung, dried crops, etc., for cooking and/or heating, would probably impact on GDP per capita.

With statistically significant error correction terms, our estimations show that the use of solid fuels negatively impacts on GDP per capita. In both the short-run and long-run analyses, our results indicate negative growth hypotheses in the solid fuels-economic development scenario for sub-Sahara Africa. Hence implying that the household use of traditional (solid) fuels for cooking and/or heating is an inhibitor to economic development within the region. This translates that the economic performance within the region is partly influenced by the amount of population having to rely on solid fuels for day-to-day activities. Although the economic development of a country is a complex dynamic influenced by several factors (and that of a region, even more complex), the level of productivity within the country (and in this case, region) still remains a large influence on the economic performance of the country. At the most simplistic level, although arguably the use of solid fuels would contribute to economic inputs (for example, serve as a form of revenue or employment for the unskilled), one could still associate the reduced productivity caused by household use of solid fuels to reduced economical productivity.

Furthermore, in the case of sub-Saharan Africa, where most countries are considered economically low-income, the hypothesis that through rising economy or better still, improved economic conditions: for example, in the way of increased household incomes, the household use of solid fuels can be addressed, is rejected by the causality estimations. As such, based on the results, our intended questions can be answered as such: enhanced economic development might play a role influencing the nature of household use of traditional (solid) fuels but ultimately, household use of traditional (solid) fuels plays a crucial role in achieving said enhanced economic development.

From a policy perspective, the implication of these findings is that changes in the household energy profile have a significant effect on changes in economy in sub-Saharan Africa. In the context of the hypotheses discussed in section 2 , our results indicate the existence of a negative-growth hypothesis between household use of solid fuels and economic development within the region. Hence, although in growth hypothesis scenarios, energy conservative policies: temporal or permanent, might hinder economic 
development; based on these results, this might be different in relation to sub-Saharan Africa. Due to the negative link, solid fuels conserving measures might not only be beneficial in preventing the inimical impacts, but also beneficial for the socio-economic development of the region. However, implementing solid-fuels reducing policies within a region where most of the population have little-to-no access to modern alternatives, might not be an ideal policy strategy. Further implication of our findings show that sub-Sahara African countries require for economic development, to increase the access to modern fuels for cooking and/or heating. Although the requirement of a hefty capital investment can be anticipated: due to declining and/or lacking infrastructures; the substantial impacts of the current situation on socio-economic development, as well as environmental sustainability, make these investments necessary and ultimately, inevitable.

Lastly, it is worth noting that the nature and effectiveness of policies will differ based on the levels of development of the countries; country-specific barriers, amongst other factors. And although we have not explored the various barriers to attaining this goal; from a policy perspective, to aid the progress towards clean cooking fuels, it can be anticipated that there is a need for policies aimed at addressing barriers to be implemented alongside modern energy accessibility policies.

All in all, it can be inferred that it is beneficial for sub-Saharan African countries to continue to strive from household use of solid fuels to clean energy - as this is likely to reinforce the much needed economic development. Finally, the relationship between the use of solid fuels for cooking and economic development needs to be further investigated. As a starting point, more attention needs to be placed on data collection. For example, although we have used panel national data in our analyses, it would be interesting to analyse the relationship using sub-national data. Sub-Saharan Africa is known to have a complex dynamics: there are vast differences across and within the countries. By using sub-national data, it might be possible to uncover some of these complex relationships within the countries.

To conclude, certainly, a better understanding of the underlying factors contributing to this issue is fundamental if the situation is to be improved. As such, more research in the area of cooking and/or heating fuels (particularly underlying barriers to access) in developing countries is necessary.

\section{Declaration of competing interest}

The authors declare that they have no known competing financial interests or personal relationships that could have appeared to influence the work reported in this paper.

\section{Acknowledgements}

Engineering and Physical Sciences Research Council (EPSRC). Grant number is EP/L016680/1.

\section{Appendix A. Supplementary data}

Supplementary data to this article can be found online at https://doi.org/10.1016/j.energy.2021.119770.

\section{Credit author statement}

Ifeoluwa Garba: Conceptualization, Methodology, Software, Validation, Formal analysis, Investigation, Resources, Data curation, Writing - original draft, Writing - review \& editing, Visualization.
Richard Bellingham: Supervision.

\section{References}

[1] United Nations Children's Fund (UNICEF). Sustainable development starts with safe, healthy and well-educated children. In: A call to action to put children at the centre of sustainable development, no. a post-2015 world fit for children. United Nations Children's Fund (UNICEF); 2013. p. 1-23. www. unicef.org/post2015/files/SD/children/FINAL.pdf.

[2] Kebede E, Kagochi J, Jolly CM. Energy consumption and economic development in Sub-Sahara Africa. Energy Econ 2010;32(3):532-7. https://doi.org/ 10.1016/j.eneco.2010.02.003. 10.1016/j.eneco.2010.02.003.

[3] Karekezi S. Poverty and energy in Africa â€" A brief review. Energy Pol 2002;30(11-12):915-9. https://doi.org/10.1016/S0301-4215(02)00047-2.

[4] Omri A. Co2 emissions, energy consumption and economic growth nexus in mena countries: evidence from simultaneous equations models. Energy Econ 2013;40:657-64. https://doi.org/10.1016/j.eneco.2013.09.003. http://www. sciencedirect.com/science/article/pii/S0140988313001989.

[5] Elias RJ, Victor DG. Energy transitions in developing countries: a review of concepts and literature. http://www.trunity.net/files/158401_158500/ 158492/elias-and-victor-2005.pdf; 2005.

[6] Gonzlez-Eguino M. Energy poverty: an overview. Renew Sustain Energy Rev 2015;47:377-85. https://doi.org/10.1016/j.rser.2015.03.013. http://www. sciencedirect.com/science/article/pii/S1364032115001586.

[7] United Nations. Work of the statistical commission pertaining to the 2030 agenda for sustainable development. 2017.

[8] Sovacool BK. The political economy of energy poverty: a review of key challenges. Energy for Sustainable Development 2012;16(3):272-82. https:// doi.org/10.1016/j.esd.2012.05.006. 10.1016/j.esd.2012.05.006.

[9] Hamilton TGA, Kelly S. Low carbon energy scenarios for sub-saharan africa: an input-output analysis on the effects of universal energy access and economic growth. Energy Pol 2017;105:303-19. https://doi.org/10.1016/ j.enpol.2017.02.012. http://www.sciencedirect.com/science/article/pii/ S0301421517300873.

[10] Clancy JS, Skutsch M, Batchelor S. The gender-energy-poverty nexus: finding the energy to address gender concerns in development. Tech. rep. 2003 Project No. CNTR998521, http://gamos.org/publications/Gender-energyDFIDCNTR998521-2003-TechReport.pdf.

[11] Iyer S, Kitson M, Toh B. Social capital, economic growth and regional development. Reg Stud 2005;39(8):1015-40. https://doi.org/10.1080/ 00343400500327943. arXiv:.

[12] Best R, Burke PJ. Electricity availability: a precondition for faster economic growth? Energy Econ 2018;74:321-9. https://doi.org/10.1016 j.eneco.2018.06.018. http://www.sciencedirect.com/science/article/pii/ S0140988318302366.

[13] Hirsh RF, Koomey JG. Electricity consumption and economic growth: a new relationship with significant consequences? Electr J 2015;28(9):72-84. https://doi.org/10.1016/j.tej.2015.10.002. http://www.sciencedirect.com/ science/article/pii/S1040619015002067.

[14] Chakamera C, Alagidede P. Electricity crisis and the effect of $\operatorname{co} 2$ emissions on infrastructure-growth nexus in sub saharan africa. Renew Sustain Energy Rev 2018;94:945-58. https://doi.org/10.1016/j.rser.2018.06.062. http://www. sciencedirect.com/science/article/pii/S1364032118305021.

[15] Ferguson R, Wilkinson W, Hill R. Electricity use and economic development. Energy Pol 2000;28(13):923-34. https://doi.org/10.1016/S0301-4215(00) $00081-1$.

http://www.sciencedirect.com/science/article/pii/ S0301421500000811.

[16] Payne JE. A survey of the electricity consumption-growth literature. Appl Energy 2010;87(3):723-31. https://doi.org/10.1016/j.apenergy.2009.06.034. http://www.sciencedirect.com/science/article/pii/S0306261909002748.

[17] Karanfil F, Li Y. Electricity consumption and economic growth: exploring panel-specific differences. Energy Pol 2015;82:264-77. https://doi.org/ 10.1016/j.enpol.2014.12.001. http://www.sciencedirect.com/science/article/ pii/S030142151400665X.

[18] World Bank Group. Clean and improved cooking in sub-saharan Africa, tech Rep. 98664. Washington DC: World Bank Group; 2014. http://documents. worldbank.org/curated/en/164241468178757464/pdf/98664-REVISED-WPP146621-PUBLIC-Box393185B.pdf.

[19] Zulu L, Richardson R. Charcoal, livelihoods, and poverty reduction: evidence from sub-saharan africa. Energy for Sustainable Development 2013;17(2): 127-37. https://doi.org/10.1016/j.esd.2012.07.007.

[20] Brew-Hammond A. Energy access in africa: challenges ahead. Energy Pol 2010;38(5):2291-301. https://doi.org/10.1016/j.enpol.2009.12.016. greater China Energy: Special Section with regular papers, http://www.sciencedirect. com/science/article/pii/S0301421509009707.

[21] Schlag N, Zuzarte F. Market barriers to clean cooking fuels in sub-Saharan Africa: a review of literature. 2008. http://sei-international.org/ mediamanager/documents/Publications/Climate/ marketbarrierscleancookingfuels21april.pdf.

[22] Olang TA, Esteban M, Gasparatos A. Lighting and cooking fuel choices of households in kisumu city, Kenya: a multidimensional energy poverty 
perspective, vol. 42. Energy for Sustainable Development; 2018. p. 1-13. https://doi.org/10.1016/j.esd.2017.09.006. http://www.sciencedirect.com/ science/article/pii/S0973082617301035.

[23] World Bank Group. Clean and improved cooking in sub-Saharan Africa, Tech. Rep. 98664. Washington DC: World Bank Group; 2014. http://documents. worldbank.org/curated/en/164241468178757464/pdf/98664-REVISED-WPP146621-PUBLIC-Box393185B.pdf.

[24] Rahut DB, Behera B, Ali A. Patterns and determinants of household use of fuels for cooking: empirical evidence from sub-saharan africa. Energy 2016;117: 93-104. https://doi.org/10.1016/j.energy.2016.10.055. http://www. sciencedirect.com/science/article/pii/S036054421631489X.

[25] Rahut DB, Behera B, Ali A. Factors determining household use of clean and renewable energy sources for lighting in sub-saharan africa. Renew Sustain Energy Rev 2017;72:661-72. https://doi.org/10.1016/j.rser.2017.01.080. http://www.sciencedirect.com/science/article/pii/S136403211730093X.

[26] Kraft J, Kraft A. On the relationship between energy and gnp. J Energy Dev 1978;3(2):401-3. cited By 11.

[27] Ozturk I. A literature survey on energy growth nexus. Energy Pol 2010;38(1): 340-9. https://doi.org/10.1016/j.enpol.2009.09.024. http://www. sciencedirect.com/science/article/pii/S0301421509007071.

[28] Garba I, Bellingham R. The impact of lack of clean cooking fuels on sustainable development in developing countries. In: ASME 2018 12th international conference on energy sustainability. ASME, Lake Buena Vista; 2018. p. 1-8. http://proceedings.asmedigitalcollection.asme.org/proceeding.aspx? articleid $=2706327$.

[29] Kaygusuz K. Energy for sustainable development: a case of developing countries. Renew Sustain Energy Rev 2012;16(2):1116-26. https://doi.org/ 10.1016/j.rser.2011.11.013. http://www.sciencedirect.com/science/article/pii/ S1364032111005491.

[30] Ouedraogo NS. Energy consumption and economic growth: evidence from the economic community of west african states (ecowas). Energy Econ 2013;36: 637-47. https://doi.org/10.1016/j.eneco.2012.11.011. http://www. sciencedirect.com/science/article/pii/S0140988312003003.

[31] Ebohon OJ. Energy, economic growth and causality in developing countries: a case study of Tanzania and Nigeria. Energy Pol 1996;24(5):447-53. https:// doi.org/10.1016/0301-4215(96)00027-4. http://www.sciencedirect.com/ science/article/pii/0301421596000274.

[32] Akinlo AE. Energy consumption and economic growth: evidence from 11 SubSahara African countries. Energy Econ 2008;30(5):2391-400. https://doi.org/ 10.1016/j.eneco.2008.01.008.

[33] Odhiambo NM. Energy consumption and economic growth nexus in Tanzania: an ardl bounds testing approach. Energy Pol 2009;37(2):617-22. https:// doi.org/10.1016/j.enpol.2008.09.077. http://www.sciencedirect.com/science/ article/pii/S0301421508005442.

[34] Esso LJ, Keho Y. Energy consumption, economic growth and carbon emissions: cointegration and causality evidence from selected african countries. Energy 2016;114:492-7. https://doi.org/10.1016/j.energy.2016.08.010. http://www. sciencedirect.com/science/article/pii/S0360544216311136.

[35] Menegaki AN, Tugcu CT. Rethinking the energy-growth nexus: proposing an index of sustainable economic welfare for sub-saharan africa. Energy Research \& Social Science 2016;17:147-59. https://doi.org/10.1016/j.erss.2016.04.009. http://www.sciencedirect.com/science/article/pii/S2214629616300718.

[36] Pachauri S, Spreng D. Measuring and monitoring energy poverty. Energy Pol 2011;39(12):7497-504. https://doi.org/10.1016/j.enpol.2011.07.008. 10.1016/j.enpol.2011.07.008.

[37] Sagar AD. Alleviating energy poverty for the world's poor. Energy Pol 2005;33(11):1367-72. https://doi.org/10.1016/j.enpol.2004.01.001. http:// www.sciencedirect.com/science/article/pii/S0301421504000096.

[38] Gunningham N. Managing the energy trilemma: the case of Indonesia. Energy Pol 2013;54:184-93. https://doi.org/10.1016/j.enpol.2012.11.018. decades of Diesel, S0301421512009834.

[39] Atems B, Hotaling C. The effect of renewable and nonrenewable electricity generation on economic growth. Energy Pol 2018;112:111-8. https://doi.org/ 10.1016/j.enpol.2017.10.015. http://www.sciencedirect.com/science/article/ pii/S0301421517306389.

[40] Bah MM, Azam M. Investigating the relationship between electricity consumption and economic growth: evidence from South Africa. Renew Sustain Energy Rev 2017;80:531-7. https://doi.org/10.1016/j.rser.2017.05.251. http://www.sciencedirect.com/science/article/pii/S1364032117308973.

[41] The World Bank. World development indicators. 2017. https://data. worldbank.org/data-catalog/world-development-indicators.

[42] Garba I, Nieradzinska K, Bellingham R. The energy poverty situation: a review of developing countries. In: Advanced studies in energy efficiency and built environment for developing countries. Springer; 2019. p. 41-9.

[43] Garba I. Cooking fuels and sustainable social development: the case of africa. In: 2019 IEEE PES/IAS PowerAfrica. IEEE; 2019. p. 622-6.

[44] Adewuyi AO, Awodumi OB. Biomass energy consumption, economic growth and carbon emissions: fresh evidence from west africa using a simultaneous equation model. Energy 2017;119:453-71. https://doi.org/10.1016/j.energy.2016.12.059. http://www.sciencedirect.com/science/article/pii/ S0360544216318655.

[45] Ozturk I, Bilgili F. Economic growth and biomass consumption nexus: dynamic panel analysis for sub-sahara african countries. Appl Energy 2015;137: 110-6. https://doi.org/10.1016/j.apenergy.2014.10.017. http://www.
sciencedirect.com/science/article/pii/S0306261914010587.

[46] Pedroni P. Critical values for cointegration tests in heterogeneous panels with multiple regressors. Oxf Bull Econ Stat 1999;61(S1):653-70. https://doi.org 10.1111/1468-0084.0610s1653. 10.1111/1468-0084.0610s1653.

[47] Kao C. Spurious regression and residual-based tests for cointegration in panel data. J Econom 1999;90(1):1-44. https://doi.org/10.1016/S0304-4076(98) 00023-2. S0304407698000232.

[48] World Health Organization. Percentage of the population with primary reliance on clean fuels and technologies at the household level. 2016. http://apps. who.int/gho/data/node.wrapper.imr?x-id=4673.

[49] Mehta S, Gore F, Prss-stn A, Rehfuess E, Smith K. Modeling household solid fuel use towards reporting of the millennium development goal indicator. Energy for Sustainable Development 2006;10(3):36-45. https://doi.org/ 10.1016/S0973-0826(08)60542-6. http://www.sciencedirect.com/science/ article/pii/S0973082608605426.

[50] Bonjour S, Adair-Rohani H, Wolf J, Bruce NG, Mehta S, Prüss-Ustün A, Lahiff M, Rehfuess EA, Mishra V, Smith KR. Solid fuel use for household cooking: country and regional estimates for 1980-2010. Environ Health Perspect 2013;121(7):784-90. https://doi.org/10.1289/ehp.1205987.

[51] Hamit-Haggar M. Greenhouse gas emissions, energy consumption and economic growth: a panel cointegration analysis from canadian industrial sector perspective. Energy Econ 2012;34(1):358-64. https://doi.org/10.1016 j.eneco.2011.06.005. http://www.sciencedirect.com/science/article/pii/ S0140988311001277.

[52] Hanif I. Energy consumption habits and human health nexus in sub-Saharan Africa. Environ Sci Pollut Control Ser 2018;(May):1-12. https://doi.org/ 10.1007/s11356-018-2336-0. http://link.springer.com/10.1007/s11356-0182336-0.

[53] Christopoulos DK, Tsionas EG. Financial development and economic growth: evidence from panel unit root and cointegration tests. J Dev Econ 2004;73(1): 55-74. https://doi.org/10.1016/j.jdeveco.2003.03.002. http://www. sciencedirect.com/science/article/pii/S0304387803001299.

[54] Al-Iriani MA. Energy-gdp relationship revisited: an example from gcc countries using panel causality. Energy Pol 2006;34(17):3342-50. https://doi.org/ 10.1016/j.enpol.2005.07.005. http://www.sciencedirect.com/science/article/ pii/S0301421505001886.

[55] Nsiah C, Fayissa B. Remittances and economic growth in Africa, Asia, and Latin American-Caribbean countries: a panel unit root and panel cointegration analysis. J Econ Finance 2013;37(3):424-41. https://doi.org/10.1007/s12197011-9195-6.

[56] Wang S, Zhou D, Zhou P, Wang Q. Co2 emissions, energy consumption and economic growth in China: a panel data analysis. Energy Pol 2011;39(9): 4870-5. https://doi.org/10.1016/j.enpol.2011.06.032. http://www. sciencedirect.com/science/article/pii/S0301421511004885.

[57] Levin A, Lin C-F, Chu C-SJ. Unit root tests in panel data: asymptotic and finitesample properties. J Econom 2002;108(1):1-24. https://doi.org/10.1016 S0304-4076(01)00098-7. http://www.sciencedirect.com/science/article/pii/ S0304407601000987.

[58] Im KS, Pesaran M, Shin Y. Testing for unit roots in heterogeneous panels. J Econom 2003;115(1):53-74. https://doi.org/10.1016/S0304-4076(03) 00092-7. http://www.sciencedirect.com/science/article/pii/ S0304407603000927.

[59] Hoang NT, McNown RF. Panel data unit roots tests using various estimation methods. 2006. http://spot.colorado.edu/ mcnownr/working_papers/panelunit-root-tests.pdf.

[60] Breitung J. The local power of some unit root tests for panel data, Nonstationary Panels. Panel Cointegration and Dynamic Panels 2000;15:161-78.

[61] Breitung J. The local power of some unit root tests for panel data. 2001 p. 161-77. https://doi.org/10.1016/S0731-9053(00)15006-6.

[62] Maddala GS, Wu S. A comparative study of unit root tests with panel data and a new simple test. Oxf Bull Econ Stat 1999;61(s1):631-52. https://doi.org/ 10.1111/1468-0084.0610s1631.

[63] Hadri K. Testing for stationarity in heterogeneous panel data. Econom J 2000;3(2):148-61. https://doi.org/10.1111/1368-423X.00043. arXiv, https:// onlinelibrary.wiley.com/doi/pdf/10.1111/1368-423X.00043. onlinelibrary.wiley.com/doi/abs/10.1111/1368-423X.00043.

[64] Pedroni P. Purchasing power parity tests in cointegrated panels. Rev Econ Stat 2001;83(4):727-31. https://doi.org/10.1162/003465301753237803.

[65] Chen B, McCoskey SK, Kao C. Estimation and inference of a cointegrated regression in panel data: a Monte Carlo study. Am J Math Manag Sci 1999;19(1-2):75-114. https://doi.org/10.1080/01966324.1999.10737475. 10.1080/01966324.1999.10737475

[66] Örsal DDK. Comparison of panel cointegration tests. 2007. https://www. econstor.eu/bitstream/10419/25201/1/558549047.PDF.

[67] Mark N, Sul D. 10.1.1.46.5610, http://citeseerx.ist.psu.edu/viewdoc/ download? $\mathrm{doi}=10.1 .1 .46 .5610 \& a m p ; r e p=r e p 1 \& a m p ;$ type $=$ pdf\% 5Cnpapers2://publication/uuid/9EB2BE32-C7A0-45F1-9784-6B19AF105B2C; 1999.

[68] Mark NC, Sul D. Cointegration vector estimation by panel dols and long-run money demand. 2002. 10.1.1.491.6229, http://citeseerx.ist.psu.edu/viewdoc/ download? \&amp;rep=rep1\&amp;type=pdf.

[69] Pedroni P. Fully modified OLS for heterogenous cointegrated panels and the case of purchasing power parity. 1996. https://pdfs.semanticscholar.org/f99a/ f7633ca11e91c6ba51446dae06f45591a573.pdf. 
[70] Bispham FD. Panel data cointegration regression estimators - a cross country consumption study. 2008. http://www.vcharite.univ-mrs.fr/colloques/2008/ davidson/2008/Papiers/Bispham.pdf.

[71] Wongkhae K, Sriboonchitta S. Does price matter? The FMOLS and DOLS estimation of industrial countries tourists outbound to four ASEAN countries. The Empirical Econometrics and Quantitative Economics Letters 2012;1(4): 107-28. http://www.jyoungeconomist.com/images/stories. 